\title{
Reunification of the Refugee Family in South Africa: A Legal Right?
}

\author{
Fatima KHaN
}

\begin{abstract}
Family unity is not considered a right within international refugee instruments and as a result the laws and policies of most states are silent in this regard. Family unity is however a legal concept which is addressed extensively in various other international law instruments. This paper contends that refugee law as a dynamic body of law is informed by these international law instruments and it should not be viewed as an isolated body of law and be denied the benefits there from. The right of family unity is often distinguished from the right to family reunification, which extends protection more specifically to families that have been separated that wish to reunite. Even though few human rights instruments specifically designate a right of family reunification it will be argued that to deny family reunification is to effectively violate the right to family unity. This paper furthermore examines the right to family reunification as it applies to refugees, looking specifically at the current status of South African and international law. It will be emphasised that because refugee law is informed by international human rights law, it can support, reinforce or supplement refugee law.
\end{abstract}

\section{Résumé}

L'unité familiale n'est pas considérée comme un droit au sein des politiques et outils internationaux concernant les réfugiés, et en conséquence, les lois et politiques de la plupart des États n'en font pas mention. Pourtant, l'unité familiale est un concept juridique dûment traité dans les autres politiques et outils du droit international. Cet article soutient que la loi sur les réfugiés, en tant que corpus dynamique de lois, est organiquement lié aux autres lois et politiques internationales, et qu'elle ne devrait pas être privée de leurs aspects positifs, en étant traitée comme un corpus isolé de lois. Le droit à l'unité familiale est parfois distingué du droit à la réunification familiale, qui étend sa protection principalement aux familles qui ont été séparées et qui souhaitent se réunir. Bien que quelques instruments juridiques du droit de la personne mentionnent spécifiquement le droit à la réunification familiale, nous soutenons que nier ce droit revient en réalité à violer le droit à l'unité familiale. Cet article examine le droit à la réunification familiale et comment il s'applique pour les réfugiés, et en particulier dans le cas de l'Afrique du Sud et du droit international. L'article souligne que les lois internationales sur les droits de la personne, parce qu'elles sous-tendent la loi sur les réfugiés, peut en fait soutenir, renforcer et compléter cette dernière.

\section{Introduction}

The refugee experience is such that it is common for family members to be separated from each other before or during their flight from their state of origin. In the face of persecution, families adopt strategies, some of which may necessitate temporary separation: sending a politically active adult into hiding, helping a son escape forcible recruitment by militia forces or sending abroad a woman at risk of attack or abduction ${ }^{1}$. Family members may be forced to take different routes out of the country or to leave at different times as opportunities permit. It is also common for refugees to be unaware, often for long periods, whether a family member is alive or dead. The commonality of the experience does not in any way detract from the pain and anxiety felt by those separated from close family members.

Refugees often go to great lengths to find lost relatives and finding a way to be reunited with them can easily assume paramount importance in a refugee's life. Jastram states that whether the separation is a 'chosen strategy or an 
unintended consequence of the chaos of forcible displacement, ${ }^{2}$ the separation of a refugee family is rarely intended to be permanent.

Unfortunately family unity is not considered a right within international refugee documents and as a result the laws and policies of most countries are silent in this regard.

Family unity is however a legal concept which is addressed extensively in various international law documents and even though there is no specific provision in the 1951 United Nations Convention Relating to the Status of Refugees $^{3}$ (hereinafter the "1951 Convention") and its 1967 Protocol $^{4}$, refugee law, as a dynamic body of law, is informed by these international law documents. Since refugee law is informed by these international law documents it should not be viewed as an isolated body of law and be denied the benefits there from.

Family unity in the refugee context means granting refugee status or a similar secure status to family members accompanying a recognised refugee. The country of asylum must likewise provide for family reunification since the refugee cannot by definition return to the state of origin to enjoy reunification there. To facilitate reunification imposes an obligation on the state and whilst it is clear that states may not arbitrarily interfere with existing family unity it is less clear whether a state should be obligated to facilitate family reunification after family members have involuntarily separated from one another.

The United Nations High Commissioner for Refugees (hereinafter "the UNHCR"), ${ }^{5}$ and many states consider family reunification a cornerstone of effective refugee protection. Regrettably, the circumstances of war and persecution that fragment refugee families are often followed by administrative and policy restrictions by countries of asylum that prolong the separation of families. This separation and trauma has been found to exacerbate the depression and trauma ${ }^{6}$ experienced by refugees and it furthermore impedes the successful establishment and integration of those in asylum states. In addition, family members left behind may be targeted for direct persecution as a result of their relation to the refugee ${ }^{7}$ diminishing protection for those who are left behind in states of origin.

This paper examines the right to family reunification as it applies to refugees, looking specifically at the current status of South African and international law. It will be emphasised that because refugee law is informed by international human rights law, it can support, reinforce or supplement refugee law. The right of family unity is often distinguished from the right to family reunification, which extends protection more specifically to families that have been separated that wish to reunite. Even though few human rights instruments specifically designate a right of family reunification, it will be argued that to deny family reunification is to effectively violate the right to family unity.

Some practical impediments facing refugees who have become separated from their families will additionally be highlighted and a specific analysis of a child's unqualified right to be united with family will be undertaken.

Given the increasingly restrictive migration policies of states, family reunification is becoming progressively more difficult; the need for new ideas and approaches is thus more compelling. In view of the fact that the concept of family unity has been visited in South African case-law, a new approach is required in the refugee context as the Refugees Act of South Africa ${ }^{8}$ is silent on the issue.

\section{The Right to Family Unity in International Law}

The right to family unity is entrenched in universal and regional human rights instruments and international humanitarian law. Even though there is no specific provision in the 1951 Convention, refugee law as a dynamic body of law, is informed by international human rights law and humanitarian law. In addition, several UNHCR Executive Committee conclusions reaffirm the state's obligation to take measures which promote and respect the unity of a family and family reunification.

\section{The 1951 Refugee Convention and its Protocol-Not an Isolated Body of Law}

Hathaway ${ }^{9}$ endorses the view that the Refugee Convention and its Protocol are part and parcel of international human rights law and not an aspect of immigration or migration. His view is fully in line with the position adopted by several foreign superior courts which have analysed the object and purpose of the Refugee Convention and its Protocol. In this regard, the Supreme Court of Canada in Canada (AttorneyGeneral) $v$ Ward $^{10}$ expressed the view that:

\footnotetext{
The essential purpose of the Refugee Convention is to identify persons who no longer enjoy the most basic forms of protection states are obliged to provide. In such circumstances refugee law provides a substitute protection of basic human rights. ${ }^{11}$
}

Similarly, the High Court of Australia in Minister for Immigration and Multicultural Affairs v. Khawar ${ }^{12}$ has linked refugee law more directly to international human rights law when it stated:

... [The Refugee Convention's] meaning should be ascertained having regard to its object, bearing in mind that the Convention is one of several important international treaties designed to redress violation[s] of basic human rights, demonstrative of the failure of state protection... . It is the recognition of the failure of state 
protection, so often repeated in the history of the past hundred years, that led to the exceptional involvement of international law in matters concerning human rights. ${ }^{13}$

Furthermore, in Applicant 'A' and Ano'r v. Minister for Immigration and Multicultural Affairs, ${ }^{14}$ the Australian court held that:

The term refugee is to be understood as written against the background of international human rights law, including as reflected or expressed in the Universal Declaration of Human Rights ${ }^{15}$ (especially Articles 3,5 and 16) and the International Covenant on Civil and Political Rights ${ }^{16}$ (especially Article 23). ${ }^{17}$

Despite the foregoing, many governments are implementing increasingly restrictive asylum policies to deter and prevent asylum seekers from seeking refuge on their territory. Manifestations of this trend includes several measures such as visa control, safe first country arrangements, stricter interpretations of the refugee definition as well as restricted family reunification rights. ${ }^{18}$ Governments have tended to justify such policies in light of the 1951 Refugee Convention provisions, without further reference or regard to other applicable human rights and humanitarian instruments.

According to the general rule of interpretation of treaties, ${ }^{19}$ treaties must be interpreted in their context and in light of their object and purpose. Refugee protection has its origins in general principles of human rights and in the refugee law context, it is generally agreed that norms of protection are framed within a human rights context.

The preamble ${ }^{20}$ to the 1951 Convention invokes the Universal Declaration of Human Rights ${ }^{21}$ as the means by which States 'have affirmed the principle that human beings shall enjoy fundamental rights and freedoms without discrimination.' This reference confirms that international refugee law was not intended to be seen in isolation. The inclusion of 'the right to seek and to enjoy asylum from persecution' in Article 14 of the Universal Declaration of Human Rights places international refugee law squarely within the human rights paradigm. ${ }^{22}$

To be able to determine the applicable standard of the refugee's right to family unity and the concomitant right to family reunification the inter-relationship between international and regional human rights law and refugee law needs to be better explored. In this regard, the following questions will be examined in this paper:

[1] Which standard should be applied in the event of a clash between the different bodies of law?;

[2] Which standard takes precedence where the 1951 Convention is either silent, as to the appropriate treatment, or offers a lower standard than international human rights law?; and

[3] Does the higher standard apply? ${ }^{23}$

\section{The Right to Family Life Under International Human Rights Law}

There are a number of provisions that elaborate on the right to family life under international human rights law. The objective, however, is to ascertain what obligations human rights instruments place on states to protect family unity and whether these obligations extend to imposing a positive obligation on states.

To begin, Article 16(3) of the Universal Declaration of Human Rights provides that 'the family is the natural and fundamental group unit of society and is entitled to protection by society and the state.' The right to family is a fundamental human right and Article 16 of the Universal Declaration of Human Rights clearly establishes this right for all peoples, regardless of status.

Protection of the family as the natural and fundamental group unit of society is also confirmed in the ICCPR, at Articles 17 and 23. ${ }^{24}$ Article 17 of the ICCPR prohibits the unlawful and arbitrary interference with families and Article 23 states that the family is the natural and fundamental unit of society entitled to protection from the state. Whereas Article 17 can be read narrowly as simply providing a basis for the right to family unity, Article 23 allows far more as outlined by Comment 19 of the UN Office of the High Commissioner for Human Rights, which states that "the right to found a family implies, in principle the possibility to procreate and live together." 25 This further implies that appropriate measures must be adopted to ensure the unity or reunification of families.

Article 10 of the International Covenant on Economic Social and Cultural Rights ${ }^{26}$ (hereinafter the "ICESCR"), confirms an obligation on states to ensure the "widest possible protection and assistance" to families. "Protection and assistance" suggests an obligation that goes further than "refrain from interference." states will have to go further and adopt measures to "protect and assist". This is beneficial in the refugee context where, at times, unity can only take place through reunification in the asylum state.

\section{The 1951 Refugee Convention and its 1967 Protocol}

Article $5^{27}$ of the 1951 Refugee Convention provides that nothing in the Convention shall impair any right or benefits granted to refugees apart from the Convention. Hence, since the right to family unity and reunification has developed in international law, it cannot be limited by provisions or lack thereof in refugee law. As stated above, the right to family unity applies to all human beings, regardless of their status. 
According to Hathaway, a broader perspective than that of the 1951 Convention is therefore necessary to understanding the scope of the right to family unity for refugees. ${ }^{28}$ The absence from the 1951 Convention of a specific provision relating to family unity does not mean that the drafters failed to see protection of the refugee family as an obligation. Hathaway argues that the 1951 Convention indeed provides protection for the refugee family in a number of its Articles. ${ }^{29}$

\section{Recommendation B}

In addition to the Preamble of the 1951 Convention, refugees' essential right to family unity was also the subject of a recommendation approved unanimously by the Conference of Plenipotentiaries that adopted the full final text of the Convention. It states:

Considering that the unity of the family, the natural and the fundamental group unit of society, is an essential right of the refugee, and that such unity is constantly threatened, and

Noting with satisfaction that, according to the official commentary of the Ad Hoc Committee on Statelessness and Related Problems, the rights granted to a refugee are extended to the members of his family,

Recommends Governments to take the necessary measures for the protection of the refugee's family, especially with a view to: (1) Ensuring that the unity of the refugee's family is maintained particularly in cases where the head of the family has fulfilled the necessary conditions for admission to a particular country: (2) the protection of refugees who are minor, in particular unaccompanied children and girls, with special reference to guardianship and adoption [Italics added] ${ }^{30}$

Hathaway ${ }^{31}$ states that while the recommendation is nonbinding, its characterisation of family unity as an "essential right" is evidence of the drafters' object and purpose in formulating the 1951 Refugee Convention. ${ }^{32}$ He states further that UNHCR Executive Committee Conclusions have repeatedly emphasised the importance of state action to maintain or re-establish refugee family unity. ${ }^{33}$

\section{The UNHCR Handbook}

The above mentioned recommendation is reproduced and elaborated in the UNHCR Handbook on Procedures and Criteria for Determining Refugee Status (hereinafter the "Handbook"). ${ }^{34}$ More specifically, paragraph 181 of the Handbook refers to the Universal Declaration of Human Rights, which states that the family is the natural and fundamental group unit of society and therefore entitled to protection. ${ }^{35}$ Paragraph 182 restates Recommendation B and paragraph 183 notes that regardless of whether or not states are party to the 1951 Convention or the 1967 Protocol the principle of family unity is observed by a majority of states giving it the status of opinio juris.

Paragraph 184 of the Handbook refers to the practice by some states of granting refugee status to the dependants of the refugee heads of households, her or his dependants are normally granted refugee status accordingly to the principle of family unity where the minimum requirement to be a dependant would include a spouse and the minor children.

Hathaway $^{36}$ further confirms that although an explicit right to family unity in the refugee context is not found in the 1951 Convention itself, the 1951 Refugee Convention must be understood in light of subsequent developments in international law, including international treaties and agreements, state practice and opinio juris. 37

\section{International Jurisprudence}

There is no uniformity in international jurisprudence largely because there is no specific mention of the refugee's family in the definition of a refugee in the 1951 Convention. Notwithstanding that the status of a refugee's family member was considered by the Ad Hoc Committee that drafted the 1951 Convention. The Committee said that 'members of the immediate family of a refugee should, in general, be considered as refugees if the head of the family is a refugee as here defined. ${ }^{38}$

In many states that are party to the 1951 Convention, there is long standing jurisprudence affirming the principle of family unity. For example, in the case of Tshisuaka and Tshilele v. Belgium, ${ }^{39}$ the $3^{\text {rd }}$ Chamber of the Belgian Conseil d'état refused to expel the spouse of a Congolese asylum seeker from Belgium on the grounds of family unity.

However, according to the Australian perspective, the absence of any provision relating to family unity or family reunification in the 1951 Convention suggests that the founders were not prepared to accept unconditional obligations relating to the families of refugees. According to the Australians, the 1951 Convention's founders regarded these issues as ultimately a matter for the judgment of the country of refuge, to be determined mainly by national asylum and immigration law and policies relating to admission criteria within the framework of international law. ${ }^{40}$

The view of the Supreme Court of the United States in Sale v Haitian Centers Council41 and the House of Lords in the UK in $T v$ Home Secretary 42 is that decisions to admit persons as refugees to the territory of member states are left to those states. 
Regional Instruments: African Standard

Human rights standards in the context of Africa are enshrined in the 1969 African Charter on Human and Peoples Rights. ${ }^{43}$ Of importance is that this Charter covers economic, social and cultural rights as well as civil and political rights. Specific mention is made of the family in Article 18 stating that the family is the natural unit of society and as such should be protected by the state. ${ }^{44}$

Also of note is Article 23 of the 1990 African Charter on the Rights and Welfare of the Child ${ }^{45}$ extending state obligation to include specific protection for refugee children. In addition it reaffirms the importance of family unity and obliges states to undertake efforts aimed at family reunification. ${ }^{46}$

The 1969 Convention Governing the Specific Aspects of Refugee Problems in Africa,47 (hereinafter the "OAU Convention") is of utmost importance in terms of refugee protection in Africa. This Convention must be viewed in relation to human rights instruments such as the African Charter on Human and Peoples Rights, mentioned above.

The drafters of the OAU Convention sought to complement rather than replace the 1951 Convention. This is reflected in Articles 9 and 10 of the Preamble, ${ }^{48}$ which stress that the 1951 Convention constitutes the basic and universal instrument relating to the status of refugees. Cognisant of the political climate in which the 1951 Convention was drafted, the drafters of the OAU Convention sought to depoliticise the issue of refugee crises as well as the concept of asylum. This is reflected in Article 2(2), which states that the "grant of asylum to refugees is a peaceful and humanitarian act and shall not be regarded as an unfriendly act by any Member State."49 Moreover, Article 2(6) states that for reasons of security, countries of asylum shall, as far as possible, settle refugees at a reasonable distance from the frontier of their country of origin. This provision was intended to discourage the setting up of refugee camps on borders, thereby increasing tensions and friction between the sending and receiving states.

\section{Family Reunification and International Law}

Family Reunification distinguished from Family Unity

The right of unity is often distinguished from the right to reunification, which extends protection more specifically to families which have been separated and wish to reunite. Many refugees are forced to leave family members behind in their country of origin and to then seek reunification once granted refugee status in the asylum state. In the context of International Refugee Law, the right to family reunification may be qualified primarily because it intersects with the right of sovereign states to control the entry of nonnationals into their territory but it is not entirely defined thereby. ${ }^{50}$ Given that the right to family unity is established in International Human Rights Law and international law, and therefore applies to all human beings regardless of citizenship or status, provisions, or lack thereof within international refugee law, cannot limit its scope. ${ }^{51}$

The right to family unity is inherent in the right to family life. ${ }^{52}$ As it is so common in the refugee experience for family members to be separated from each other before or during their flight from the country of origin, for refugees, the right to family unity implies a right to family reunification in the country of asylum. More specifically, the refugee cannot return to his or her country of origin to enjoy the right to family unity there.

The right to marriage and family as established within International Human Rights Law entails contrasting obligations on states. On the one hand, states are obliged to refrain from taking action that disrupts families and it is now widely recognised that states must take positive steps to reunite families if they have been separated especially if they are unable to reunite elsewhere. ${ }^{53}$

Indeed, the 1951 Convention does not incorporate the principle of family unity. Nevertheless, UNHCR notes that most states respect the principle and that a failure to allow for family reunification and thereby for family unity, is interpreted as a violation of the right as opposed to evidence that the right does not exist. In this regard, the UNHCR states that the "... [r]efusal to allow family reunification may be considered as an interference with the right to family life or to family unity, especially where the family has no realistic possibilities of enjoying the right elsewhere." 54

Few international human rights instruments specifically deal with the right to family reunification, among these, the 1975 Helsinki Declaration. ${ }^{55}$ Although this Declaration is not binding as it does not have treaty status, it is persuasive in that is demonstrates the participant parties' intentions.

Anderfuhren-Wayne ${ }^{56}$ notes that at least among some industrialised states, there is a policy of allowing admission of persons who have been separated from their families, where reasonable, noting that states are under a political and moral obligation to conduct their immigration policies so as to avoid unnecessary disruption to family life. ${ }^{57}$ It can be argued that refusal to allow family reunification may be considered interference to the right to family unity especially where there is no realistic possibility of the family enjoying that right elsewhere. States should facilitate admission to their territories, at least where it would be unreasonable to expect the families to be reunited elsewhere.

\section{The Elsewhere Approach}

The Elsewhere Approach was largely developed by the European Court of Human Rights. ${ }^{58}$ It is an approach 
which offers support to the plight of refugee families because, more often than not, refugees cannot be reunited elsewhere but in the country of reception. According to the Elsewhere Approach, expulsion or exclusion of a family member is legitimate if other family members can follow and if this can be reasonably expected of them. A determination of reasonableness involves weighing the advantages and disadvantages to the concerned individual against the interest of the state served by its immigration policy. The determining criteria adopted by the European Court for Human Rights include amongst others:

- Consideration of one's ties with the state denying entry;

- Links with the foreign country;

- The economic consequences of moving to another country;

The European Court of Human Rights has decided in two non-refugee cases that a state must allow family reunification if it is the only way for a family to achieve family unity. ${ }^{59}$

Whilst the Gul case ${ }^{60}$ appears to be a narrowing of the right to family reunification because the applicants could reunite elsewhere-they were not allowed to reunite in Switzerland in this case-the decision bodes well for refugee family reunification. The facts of the case were as follows. The applicant, Mr. Gul, had arrived in Switzerland seeking asylum as he feared political persecution in Turkey due to his membership of a party opposed to the government's actions in South East Turkey. However, once granted a humanitarian permit, he dropped his claim for asylum status. His wife who suffered from epilepsy was allowed to join him three years later for humanitarian reasons. The applicants sought to be reunited with their son on the basis that it was impossible for them to return to their son. The government argued that it was possible for them to return to Turkey and reunite with their son and therefore Switzerland had no obligation to allow family reunion in Switzerland.

Although the above approach has largely been used in terms of immigration matters, in the European Union, its applicability and value to refugee matters is significant. Firstly, the refugee family would only request reunification of a family member if it has established itself in the receiving state. Secondly, it would have nowhere else to go and by the very definition of a refugee, it could not back to its country of origin, unless resettlement to a third country is an option.

\section{The Humanitarian Approach}

There are various international resolutions stressing the importance of reunification in connection with the principle of family unity. The Fourth Geneva Convention of $1949^{61}$ devoted considerable attention to the problems of families dispersed owing to war. In addition to provisions aimed at maintaining family unity during a wartime evacuation, the Fourth Geneva Convention provides for mechanisms such as family messages, tracing of family members, and registration of children to enable family communication and if possible family reunification.

Furthermore, in 1981, the UNHCR Executive Committee concluded, with regard to family reunification and refugees, as follows:

In the application of the principle of the unity of the family and for obvious humanitarian reasons, every effort should be made to ensure the reunification of separated families. It is hoped that the countries of asylum will apply liberal criteria in identifying those family members who can be admitted with a view to promoting a comprehensive reunification of the family. ${ }^{62}$

Similarly, the conclusions of the Thirteenth Round Table of the Institute of Humanitarian Law have stressed reunification in connection with unity:

The humanitarian principle of family reunification is firmly established in international practice ... This principle is closely linked to the right of the unity of the family which recognises that the family is the natural and the fundamental group unit of society and is entitled to protection by society and the state... . [T]here exists different situations where families need to be reunited, solutions must be reached in accordance with relevant international law and the requirements of the particular situation. ${ }^{63}$

For many years, the International Red Cross and Red Crescent Movement has played a major role in preserving family unity and integrity, particularly in facilitating the reunification of families dispersed by war or as a consequence of persecution. Various resolutions of the movement's international conferences encourage national societies, governments and international bodies to facilitate family reunification.

Family reunification often begins with the tracing of separated family members. Recommendations of the $26^{\text {th }}$ International Conference of the Red Cross and Red Crescent Movement state that national societies should:

... [m]aximise their efficiency in carrying out tracing work and family reunification by strengthening their tracing and social welfare activities and maintaining close cooperation with the ICRC and government authorities and other competent organisations such as the UNHCR the International Organisation of Migration. ${ }^{64}$ 
Family reunification should therefore be considered as a means of implementing the principle of family unity. If a right should be recognised by states concerning the reunion of the family, it is more a right to enter and live in the receiving state or a right to the protection of the family unit rather than a right to family reunification.

From the above it is apparent that there is no lack of international standards regarding the principle of family unity, rather the issue is with their implementation being hampered by administrative restrictions.

\section{The Child's Right to Family Reunification in International Law}

The Convention on the Rights of the Child ${ }^{65}$ appears to provide the most holistic and assertive pronouncement on the right to family reunification.

In recent years there has been recognition that unaccompanied and separated children are particularly vulnerable and that states face various challenges in providing such children access and enjoyment of their rights. A General Comment ${ }^{66}$ was issued in 2005 motivated by the UN Committee of the Rights of the Child's observance of an increasing number of children in such situations. There are varied and numerous reasons for children being unaccompanied ${ }^{67}$ or separated, ${ }^{68}$ ranging from persecution of the child or the parents; to international conflict and civil war to trafficking in various contexts and forms, certainly the number of unaccompanied or separated children are a growing cause of concern within the refugee sphere.

The right to family reunification for minor children and their parents is codified in the Convention on the Rights of the Child at Article 10:

In accordance with the obligations of States Parties under article 9, paragraph 1 [a child shall not be separated from his or her parents against their will], applications by a child or his or her parents to enter or leave a State Party for the purpose of family reunification shall be dealt with by States Parties in a positive, humane and expeditious manner. ${ }^{69}$

Several elements of this provision are noteworthy:

- First, the explicit link to the Convention of the Rights of the Child in Article 9 means that the obligation there imposed to ensure the unity of families within the state also determines the states' actions regarding families divided by borders.

- Second, one of the Convention of the Rights of the Child's achievements is the recognition that reunification may require a state to allow entry as well as departure.
- Third, children and parents have equal status in a mutual right; either may be entitled to join the other. It is not sufficient that the child be with only one parent in an otherwise previously intact family; the child has the right to be with both parents, and both parents have the right and responsibility to raise the child.

- Fourth, the obligation on states to deal with reunification requests in a 'positive' and 'humane' manner means, in most cases, an affirmative manner.

- Lastly, that parties shall cooperate with the United Nations to protect and assist a refugee child and to trace the parents or other members of the family of the refugee child in order to obtain information necessary for reunification with his or her family.

While Article 10 does not expressly mandate approval of every family reunification application, ${ }^{70}$ it clearly contemplates that there is at least a presumption in favour of approval. ${ }^{71}$ The formulation of Article 10 is considerably strongly worded and does not allow much room for significant state discretion, such as 'consider favourably,' 'take appropriate measures,' or 'in accordance with national law.' Anderwuhren-Wayne ${ }^{72}$ asserts that states enjoy extensive discretion but she does not identify the basis for this discretion. States cannot maintain generally restrictive laws or practices regarding the entry of aliens for reunification purposes without violating the Convention of the Rights of the Child. ${ }^{73}$

Goodwin-Gill asserts that reservations made by a small number of states to the reunification provision provide additional confirmation that the Convention on the Rights of the Child indeed imposes a general duty to allow entry for family reunification purposes. ${ }^{74}$ While it may be argued that state practice is not uniform, outright failures to allow reunification are more properly seen as violations of the right, not as evidence that there is no right. ${ }^{75}$

As with the right to family unity, experts are almost universally in agreement that there is at present a right under international law to family reunification. ${ }^{76}$ It has been characterized as a self-evident corollary to the right to family unity $^{77}$ and the right to found a family ${ }^{78}$ and has been linked to freedom of movement.

In sum, it is now widely recognized that a state is obliged to reunite close family members of a non-citizen on its territory if they are unable to enjoy the right to family unity in their own country, or elsewhere.

\section{South African Refugee Law}

The Refugees Act of South Africa ${ }^{79}$ reflects the principles contained in various international instruments dealing with refugees. ${ }^{80}$ The 1951 Refugee Convention specifically obliges state parties to grant refugees either the same 
treatment as nationals of that state or, as a minimum, 'the most favourable treatment accorded to nationals of a foreign country in the same circumstances' 81 in respect of a variety of different rights. The OAU Convention is less specific, but does commit member states to "... [u]se their best endeavours consistent with their respective legislations to receive refugees and to secure the settlement of those refugees who, for well-founded reasons, are unable or unwilling to return to their country of origin or nationality." 82

Both Conventions state that their provisions shall be applied without discrimination. ${ }^{83}$ All persons in South Africa share a certain set of basic human rights under international law, regardless of their immigration status. Refugees have, in addition, rights based on international refugee law and the principle of non-refoulement, that persons should not be returned to a country where they fear persecution on the grounds of race, religion, nationality, membership of a particular social group, or political opinion, or which they were compelled to leave owing to external aggression, occupation, foreign domination or events seriously disturbing public order.

\section{An Analysis of the Refugees Act (130 of 1998)}

The Refugees Act in its preamble ${ }^{84}$ refers to South Africa's acceptance of its obligations under international law and the "other human rights instruments" to which it is a party. The Act refers specifically to South Africa acceding to the 1951 Convention and the OAU Convention. In addition, in a substantive section of the Refugees Act, at section $6,{ }^{85}$ an interpretation in terms of the Universal Declaration of Human Rights and any other international agreement to which South Africa is a party is demanded thus clearly paving the way for a human rights interpretation of the Refugees Act. On the issue of family unity and family reunification, as discussed above, the human rights approach is the preferred approach if the domestic law is silent as is the case with the South African Refugees Act.

Beneficial to refugees generally and with regard to family unity in particular is the fact that the South African Refugees Act provides a more extensive definition of a refugee, than both the 1951 Convention and the OAU Convention; it includes dependants of recognized refugees as being refugees themselves. ${ }^{86}$ South Africa thus affords derivative status to the dependant, which automatically includes immediate family members of the recognised refugee. This provision recognizes that not all members of a family necessarily have refugee claims; and it furthermore respects the family as a unit. This is the preferred approach in the light of the fact that the granting of refugee status is meant to be a form of surrogate protection. The host country should strive to provide protection to the refugee not just by physically protecting him or her from persecution, which would be minimum protection, but also so that he or she may live in dignity.

Nowhere in the Refugees Act does it stipulate that a dependant or a family member must be present in South Africa at the time of status determination of the principal applicant. There is therefore nothing in the Act which bars a claimant to seek derivative status even if the claimant arrives at a date later than the principal refugee.

The definition of dependant in section 1 of the Refugees Act includes, "spouse, any unmarried dependent child or destitute, aged or infirm member of the family of the refugee or asylum seeker." 87 While there is not enough clarity of who is considered a member of the family, this is already recognition that the family is more than what is generally considered a nuclear family. The concept of what constitutes a family varies from state to state, and in some circumstances, within regions of a state. The absence of an agreed definition has meant that states may define the term according to their own interest, culture and system. ${ }^{88}$

There is no universally accepted definition of the family, and international law recognizes a variety of forms; ${ }^{89}$ more specifically, that a family consists of those who consider themselves and are considered by each other to be part of the family, and who wish to live together. ${ }^{90}$ In the refugee context, states have shown a willingness to promote "liberal criteria" with a view toward "comprehensive reunification" of families. ${ }^{91}$ Given the range of variations on the notion of family, a flexible approach is needed. ${ }^{92}$

The Refugees Act provides that refugees in South Africa are entitled to the protection of the Bill of Rights ${ }^{93}$ of the South African Constitution. ${ }^{94}$ Since refugees are afforded the same rights as South Africans a broader definition of who is family should be considered in light of the fact that South Africa's Customary Marriages Act ${ }^{95}$ has accepted a broader definition of family than the nuclear family. In this regard, polygamous marriages and their offspring are already considered legitimate in terms South African law.

The Constitution also gives effect to customary law, which allows for a broader definition of family. The South African Constitutional Court has affirmed the following in this regard:

These stereotypical and stunted notions of marriage and family must now succumb to the newfound and restored values of our society, its institutions and diverse people. They must yield to societal and constitutional recognition of expanding frontiers of family life and intimate relationships. Our Constitution guarantees not only dignity and equality but also freedom of religion and belief. What is more, s 15(3) 100 of the Constitution foreshadows and authorises legislation that recognises marriages concluded 
under any tradition or a system of religious, personal or family law. ${ }^{96}$

South Africa's broader definition of a family is indeed a more realistic and more inclusive way of defining a family as it takes account the diversity of peoples and the evolving nature of the family. This definition should be thus adopted in any approach that South Africa formulates in terms of family reunification.

\section{The Principle of Family Unity and South African Law} Except for Section 28 of the South African Constitution, ${ }^{97}$ which describes a child's right to family care, there is no specific right to family in the Constitution or any other statute in South Africa.

However, in a ground breaking judgment, Dawood $v$. Minister of Home Affairs 98 the Cape High Court held that the right to dignity must be interpreted to afford protection to the institutions of marriage and family life. The Constitutional Court thereafter confirmed the approach and held that the Constitution indeed protected the rights of persons to freely marry and raise a family. The court stated that:

Section 25(9)(b) of the [Aliens Control] Act also fell foul of the right to human dignity protected in $\mathrm{s} 10$ of the Constitution, both of South African permanent residents who were married to alien non-resident spouses, as also of such alien spouses. The practical effect of s 25(9)(b) was that, although an alien spouse married to a South African permanent resident was in fact living in South Africa with her or his spouse, the alien spouse could be compelled to leave South Africa and to remain outside the country while her or his application for an immigration permit was being submitted to and considered by the relevant regional committee. This would result in a violation of the core element of the alien spouse's right to family life and thus a violation of her or his right to human dignity. Accordingly, s 25(9)(b) also constituted an infringement or a threatened infringement of the South African permanent resident spouse's right to human dignity. ${ }^{99}$ [emphasis included]

Even though the Refugees Act is silent with regards to family reunification, in terms of the Dawood judgment it may not be necessary for refugees to invoke international instruments ${ }^{100}$ for the reason that in terms of the South African Bill of Rights, once inside South Africa, foreign nationals are entitled to the same rights available to "everyone"101 in the Republic except those that are specifically set aside for citizens such as the right to vote or hold public office. This together with the importance of family unity places an obligation on South Africa to allow for the reunification of refugee families within South Africa.

\section{Practical Impediments}

Whilst there is ample evidence of a right to family reunification for refugees in international law and an even stronger case in South African domestic law, there remain many practical impediments to actual family reunification in South Africa.

Firstly, the Refugees Act at Section 33 only refers to dependants of recognized refugees and their rights and obligations in the Republic. Secondly, the Act does not prescribe a method for bringing dependants of refugees across South Africa's borders. There is no existing policy or implementation procedure developed by the government even though arguably the right to family unity and the concomitant right to family reunification exist in principle for refugees in South Africa.

\section{When the Family Member is Present in South Africa}

The administrative process to join a spouse or a dependant of a refugee to a main applicant's asylum application file at the Department of Home Affairs ${ }^{102}$ has in the past not proved to be so problematic. ${ }^{103}$ The application would be made in terms of Section 3(c) of the Refugees Act, and the refugee would present him or herself to the refugee reception office and request family joining with a specific member or members of his or her family seeking asylum. In addition to the principal applicant having had to declare his or her spouse and children in the initial asylum application form, the applicant would also have to supply documentary evidence of the relationship with the family member, such as marriage certificate, birth certificate, evidence of cohabitation, or any documentary evidence to prove a relationship issued by the relevant authority of the country of origin such as identity documents. ${ }^{104}$

As the refugee regime in South Africa has matured, more impediments to the smooth joining process of spouses or dependants of refugees, who arrive on their own to join their family members, is becoming evident. ${ }^{105}$ Unfortunately, due to the fact that no specific family joining system is in place in South Africa for refugees, Department of Home Affairs officials often refuse a family member's application on the basis of a more restrictive reading of the Refugees Act, in particular that of Regulation 16, which states that “... [d] ependants who accompanied the asylum applicant to the Republic may apply for refugee status pursuant to section 3(c) of the Act [emphasis added]."106

A broader, human-rights approach interpretation of the Refugees Act on this point should allow for any dependant or spouse to get derivative status, no matter whether they arrive at a later date, after the principal applicant applied for asylum. The refugee definition in the Act itself makes no distinction whatsoever in Section 3(c) between a dependant 
who accompanies the main applicant upon making the application or who arrives at a later date.

\section{When the Family Member is Present in the Country of Origin or a Third Country}

In South Africa, for a refugee to be able to facilitate reunification with his or her immediate family members outside of the country will require an amendment to legislation, despite as shown above, the fact that the right to family unity and the concomitant right to reunification can be argued to exist in South Africa.

In South Africa, family unity concerns more commonly arise in relation to reunification, rather than refusal of entry at the border. This is due to the fact that when it comes to immigration rights deriving from the principle of family unity, the situation is unclear. A specific right to enter the country is not explicitly stated either in the Refugees Act or the Immigration Act. ${ }^{107}$

The nature of a genuine refugee's flight from persecution or conflict in their state of origin often means that families are divided. This happens for a number of reasons: persons seeking asylum often do not have the choice of making sure that the entire family is seeking asylum at the same time. This is often the case with conflict in Africa, where the predominant number of South Africa's refugees hail from. Factions may attack a village or region without warning causing people to flee. In the confusion, families will often lose track of each other. It is only when they are in the country of asylum that they are able to access the services or communicate through friends and family to find where their family members have fled to.

Sometimes, families choose to leave their country of origin at different times; one member may choose to leave due to the danger to their own family and thus protect them from persecution. Once they reach their country of refuge, they may then decide to bring their family to stay with them. This is often the case when it is the breadwinner who had to leave but still needs to support his or her family.

Parents may leave their children behind in the state of origin because they are fearful that the voyage to the state of refuge is fraught with dangers. It is only when they arrive in the state of refuge that they feel that they can access a government or UNHCR programme to have their children safely brought to join them.

Refugees may leave their families behind under the protection of other people, but those situations may change. Children are often left with other relatives or neighbours. If something were to happen to those people, the child is then left without any support. This may lead to a situation where it is imperative to have the children join their parents.
The problem however arises when dependants who find themselves in third party states or still in their in state of origin request to join their family members in South Africa. Those refugees will then search for legitimate means to bring their families to join them legally. It is in the absence of legal means that people may turn to clandestine means of having their family members join them. This may lead to dangerous border crossings, corrupt payments of border officials, and fears of large-scale smuggling cloaked as family reunification.

For South Africa to be able to facilitate reunification for refugees as a means to ensure the full protection of refugees, it needs to lay a firm foundation for family unity and family reunification in its domestic legislation. Jastram ${ }^{108}$ confirms that such provisions are an important method of implementing international standards and represent the best practice in a rights-based approach to protection of the refugee family.

In both Canada and Australia where derivative status is not permitted, separate administrative procedures still exist to ensure family unity, for example, a family sponsorship category within the country's immigration regime, although such procedures may be cumbersome and cause pain and hardship to refugees seeking family reunification. In light of this, it is suggested that South Africa should incorporate family unity and family reunification into its existing refugee legislation as simply and as elegantly included by Bosnia-Herzegovina:

\footnotetext{
Refugee status shall in principle be extended to the spouse and minor children as well as other dependants, if they are living in the same household. Entry visas shall be provided to such persons to whom asylum has been granted. ${ }^{109}$
}

The Refugee Act of Iraq is even more succinct, stating that “... $\mathrm{t}$ ] he person who has been accepted as a refugee in Iraq shall be allowed to bring his/her family members legally recognised as dependants." 110

\section{Conclusion}

South Africa's obligations in law require that it set up a system so that otherwise law-abiding people will not turn to clandestine ways of reuniting with their families. In terms of international law and its domestic law, South Africa is obligated to set up a family reunification process for refugees in South Africa so that people are not forced to turn to methods which can result in violence, people smuggling, and further suffering.

While the 1951 Convention remains the central document in terms of international refugee law, at the same time it is acknowledged that the document does not cover 
or deal with the range of issues facing refugees today. This paper has demonstrated how refugee law is informed by International Human Rights Law and how it can be used to supplement refugee law, thereby broadening the scope of the 1951 Convention and also strengthening and enhancing existing standards.

Despite the lack of a unified approach internationally, there is a clear understanding of the right to family unity. The right to family life is a clear example of protection afforded to refugees that is inadequate under the 1951 Convention. However other forms of international law and case-law provide authority that the family is an essential institution and indicate a clear concern both for its preservation as well as its promotion.

Refugee law is without a doubt a compromise between the sovereignty of a state and the humanitarian needs of a group of people, arguably a group more vulnerable than any other in society. Most states, including South Africa, are however implementing this right more so from a sovereignty perspective than a protection right for families. Even though the right to the reunification of refugee families cannot escape the competing interest of the individual and the state, it is argued that the actual family situation should be the ultimate determining factor if the family life is to be protected. It is submitted that the question of family unity should be considered from a positive obligation perspective rather than a sovereignty position and the humanistic quality in this area of law must be encouraged.

\section{Notes}

1. Kate Jastram and Kathleen Newland, "Family Unity and Refugee Protection," in Refugee Protection in International Law: UNHCR's Global Consultations on International Protection, ed. E. Feller et al (Cambridge University Press, 2003).

2. Ibid.

3. Convention Relating to the Status of Refugees, 28 July 1951, 189 U.N.T.S. 150 (entered into force 22 April 1954).

4. Protocol Relating to the Status of Refugees, 31 January 1967, 606 U.N.T.S. 267 (entered into force 4 October 1967).

5. The Office of the High Commissioner is entrusted, inter alia, with the task of promoting international instruments for the protection of refugees, and supervising their application. Under the Convention and the Protocol, contracting states undertake to cooperate with the Office of the UNHCR in the exercise of its functions and, in particular, to facilitate its specific duty of supervising the application of the provisions of these instruments (Introductory note to the 1951 Convention, Geneva, March 1996).

6. C. Rousseau et al. "Trauma and Extended Separation from family among Latin American and African Refugees in Montreal," (Spring 2001), 64 Psychiatry 1, 40.
7. Jastram, Family Unity, 555, 558.

8. The Refugees Act (130 of 1998).

9. James C. Hathaway, The Rights of the Refugee under International Law (Cambridge: Cambridge University Press, 2005).

10. Canada (A.G.) v. Ward [1993] 2 S.C.R. 689, 103 DLR 4th 1.

11. Hathaway, The Rights of Refugees, 4.

12. Minister for Immigration and Multicultural Affairs v. Khawar, [2002] HCA 14 (Aus. HC, April, 11, 2002).

13. Ibid, per Kirby J.

14. Applicant 'A' and Ano'r v. Minister for Immigration and Multicultural Affairs, [1997] 190 CLR 225 (Aus. HC, Feb. 24 1997). The articles are discussed below.

15. Universal Declaration of Human Rights 10 December 1948, 217 A (III).

16. International Covenant on Civil and Political Rights 19 December 1966, 999 U.N.T.S. 171 (entered into force 23 March 1976), hereinafter "the ICCPR."

17. Applicant 'A' and Ano'r, 296-97.

18. Alice Edwards "Human Rights, Refugees, and the Right 'to enjoy' Asylum," International Journal of Refugee Law 17(2) (2005): 294.

19. Vienna Convention on the Law of Treaties, 23 May 1969, 1155 U.N.T.S. 331 (entered into force 27 January 1980), Art. 31 (2) states that 'the context for the purpose of the interpretation of a treaty shall comprise, in addition to the text, including its preamble and annexes:

(a) any agreement relating to the treaty which was made between all the parties in connexion with the conclusion of the treaty;

(b) any instrument which was made by one or more parties in connexion with the conclusion of the treaty and accepted by the other parties as an instrument related to the treaty'

20. The European Court of Human Rights in Golder $v$ United Kingdom (1975) E.H.R.R. 524, par 34, has noted that the preamble of an international convention may be used to determine its object and purpose.

21. Considering that the Charter of the United Nations and the Universal Declaration of Human Rights approved on 10 December 1948 by the General Assembly have affirmed the principle that human beings shall enjoy fundamental rights and freedoms without discrimination.

22. Erika Feller, "International refugee protection 50 years on: The protection challenges of the past, present and future" (2001) 83 International Review of the Red Cross, 843.

23. Edwards, Human Rights, 295.

24. ICCPR, Article 23 states that:

1. The family is the natural and fundamental group unit of society and is entitled to protection by society and the State;

2. The right of men and women of marriageable age to marry and to found a family shall be recognized;

3. No marriage shall be entered into without the free and full consent of the intending spouses; 
4. States Parties to the present Covenant shall take appropriate steps to ensure equality of rights and responsibilities of spouses as to marriage, during marriage and at its dissolution. In the case of dissolution, provision shall be made for the necessary protection of any children.

25. Office of the High Commissioner for Human Rights, General Comment No. 19: Protection of the family, right to marriage and equality of spouses (Art.23): 1990/07/27, Par 5.

26. International Covenant on Economic, Social and Cultural Rights, 16 December 1966, 993 U.N.T.S. 3 (entered into force 3 January 1976).

27. The 1951 Convention, Art. 5.

28. Hathaway, The Rights of Refugees, 569.

29. Ibid., 569. The 1951 Convention, Art. 4, refers to refugees' freedom as regards the religious education of their children; Art. 12(2) provides that the rights to marriage shall be respected; Art. 22 concerns the public education of children in public schools and Art. 24 concerns family allowances and other related social security as may be offered to nationals.

30. Final Act of the United National Conference of Plenipotentiaries on the status of Refugees and Stateless Persons, 1951, UN doc.A/CONF.2/108/Rev.1, 25 July 195, Recommendation B, accessed on 15 August 2011 at http://www.unhcr. org/refworld/docid/40a8a7394.html.

31. Hathaway, The Rights of Refugees, 569.

32. Ibid.

33. Ibid. Hathaway quotes the following UNHCR Executive Committee Conclusions: Nos. 1 (XXVI), 1975, para. f. Conclusion No. s 9 (XXVIII), 1977; 24 (XXXII), 1981; 84 (XLVIII), 1997; 85 (XLIX), paras. u-X; 88(L), 1999.

34. United Nations High Commissioner for Refugees, Handbook on procedures and criteria for determining refugee status under the 1951 Convention and the 1967 Protocol relating to the Status of Refugees, HCR/1P/4/Eng/Rev.2, accessed on 15 August 2011, at http://www.unhcr.org/refworld/docid/3ae6b3314.html.

35. Hathaway, The Rights of Refugees, 569.

36. Ibid.

37. Ibid.

38. UN Doc E/EAC.32/5(E/1618), cited in Grahl-Madsen 1966 Vol1 413

39. Tshisuaka and Tshilele v. Belgium No. 39227, 2 April 1992, 68 Revue du droit des estrangers 66.

40. Interpreting the Refugees Convention-An Australian contribution, found at http://www.immi.gov.au. 181

41. Sale v Haitian Centers Council (1993) 125 L Ed 2d 128.

42. T V Home Secretary (1996) AC 742.

43. African Charter on Human and Peoples' Rights 27 June 981, OAU Doc. CAB/LEG/67/3 rev. 5, 21 I.L.M. 58 (1982), (entered into force 21 October 1986).

44. Art. 18
1. The family shall be the natural unit and basis of society. It shall be protected by the State which shall take care of its physical health and moral;

2. The State shall have the duty to assist the family which is the custodian of morals and traditional values recognized by the community;

3. The State shall ensure the elimination of every discrimination against women and also ensure the protection of the rights of the woman and the child as stipulated in international declarations and conventions;

4. The aged and the disabled shall also have the right to special measures of protection in keeping with their physical or moral needs.

45. African Charter on the Rights and Welfare of the Child, 11 July 1990, OAU (Doc. CAB/LEG/24.9/49, (entered into force 29 November 1999).

46. African Charter, Article 23: Refugee Children states that: 1. States Parties to the present Charter shall take all appropriate measures to ensure that a child who is seeking refugee status or who is considered a refugee in accordance with applicable international or domestic law shall, whether unaccompanied or accompanied by parents, legal guardians or close relatives, receive appropriate protection and humanitarian assistance in the enjoyment of the rights set out in this Charter and other international human rights and humanitarian instruments to which the States are Parties.

2. States Parties shall undertake to cooperate with existing international organizations which protect and assist refugees in their efforts to protect and assist such a child and to trace the parents or other close relatives or an unaccompanied refugee child in order to obtain information necessary for reunification with the family. 3. Where no parents, legal guardians or close relatives can be found, the child shall be accorded the same protection as any other child permanently or temporarily deprived of his family environment for any reason.

4. The provisions of this Article apply mutatis mutandis to internally displaced children whether through natural disaster, internal armed conflicts, civil strife, breakdown of economic and social order or howsoever caused.

47. Convention Governing the Specific Aspects of Refugee Problems in Africa, 10 September 1969, 1001 U.N.T.S. 45, (entered into force 20 June 1974), hereinafter the "OAU Convention."

48. OAU Convention, Preamble, Article 9 states that "Recognizing that the United Nations Convention of 28 July 1951, as modified by the Protocol of 31 January 1967, constitutes the basic and universal instrument relating to the status of refugees and reflects the deep concern of States for refugees and their desire to establish common standards for their treatment." Further, OAU Convention, Preamble, Article 10 states that "Recalling Resolutions 26 and 104 of the OAU Assemblies of Heads of State and Government, 
calling upon Member States of the Organization who had not already done so to accede to the United Nations Convention of 1951 and to the Protocol of 1967 relating to the Status of Refugees, and meanwhile to apply their provisions to refugees in Africa."

49. OAU Convention, Article 2(2).

50. Hathaway, The Rights of Refugees, 576.

51. Ibid.

52. Ibid., 556.

53. Edwards, Human Rights, 314.

54. United Nations High Commissioner for Refugees, "Summary Conclusions on Family Unity Global Consultations on International Protection, Geneva Expert Roundtable," (8-9 November 2001), organised by the UNHCR and the Graduate Institute of International Studies, paragraph 5, accessed on 1 July 2012, at http://www.unhcr.org/refworld/ publisher,CUP,THEMGUIDE,,470a33bed,0.html.

55. The Final Act of the Conference on Security and Cooperation in Europe, 1 August 1975, 14 I.L.M. 1292 (the Helsinki Declaration). although not binding as it did not have treaty status, Article (1)(b) Reunification of Families states that the "participating States will deal in a positive and humanitarian spirit with the applications of persons who wish to be reunited with members of their family, with special attention being given to requests of an urgent charactersuch as requests submitted by persons who are ill or old."

56. Cynthia S. Anderfuhren-Wayne, "Family Unity in Immigration and Refugee matters: United States and European Approaches," International Journal of Refugee Law, Volume 8, No. 3 (July 1996) 349.

57. Ibid.

58. Gul v Switzerland, 19 February 1996, No. 53/1995/559/645 and Ahmed $v$ Netherlands, 28 November 1996, No. 73/1995/579/665.

59. Ibid

60. Ibid.

61. Geneva Convention Relative to the Protection of Civilian Persons in Time of War (Fourth Geneva Convention), 12 August 1949, 75 U.N.T.S. 287 (entered into force 21 October 1950), defines humanitarian protection for civilians in a war zone.

62. United Nations High Commissioner for Refugees Executive Committee, Conclusion No.24 (XXXII) Family Reunification, 21 October 1981, sections 1, 5.

63. International Review of the Red Cross, Conclusions on Family Reunification, 1988, (formulated at the thirteenth Round Table of the International Institute for Humanitarian Law, San Remo, 6-10 Sept.1988), Conclusions 1, 2 and 3.

64. Ibid.

65. Convention on the Rights of the Child, 20 November 1989, 1577 U.N.T.S. 3 (entered into force 2 September 1990).

66. UN Committee on the Rights of the Child, "CRC General Comment No.6 (2005): Treatment of Unaccompanied and
Separated Children Outside their Country of Origin," 1 September 2005, CRC/GC/2005/6

67. Unaccompanied children are children, as defined in Art. 1 of the Convention of the Rights of the Child, who have been separated from both parents and other relatives and are not being cared for by an adult who, by law or custom, is responsible for doing so. According to the UNHCR the term unaccompanied minor rather than orphan should be used .An child is an orphan only if both parents are dead and this requires a careful verification and must never be assumed. Once a child is labelled an orphan adoptions are encouraged rather than focussing on family tracing, foster placement and community support.

68. Separated children are children, as defined in article 1 of the Convention, who have been separated from both parents, or from their previous legal or customary primary care-giver, but not necessarily from other relatives. These may therefore include children accompanied by other adult family members.

69. Convention on the Rights of the Child, (1989) Art. 10(1).

70. Sharon Detrick, The United Nations Convention on the Rights of the Child: A Guide to the "Travaux Preparatoires, (Dordrecht: Martinus Nijhoff,1992), 206.

71. Jastram, Family Unity, quoting P.J. van Krieken, "Family Reunification," in The Migration Acquis Handbook (ed. P. J. van Krieken, T.M.C. Asser Press, The Hague, 2001) 123, who acknowledged that Art. 10 does not 'leave much room for machination and manipulation.'

72. Anderfuhren-Wayne, "Family Unity."

73. E.F. Abram, "The Child's Right to Family Unity in International Immigration Law," Law and Policy, 17(4) (1995) 423-4 confirms that a "state cannot as a matter of law or policy determine that family reunification for a category of sundered families will take place somewhere else in the world, and that family unity will be respected only by ushering the local child or parent to the airport. There is no true observation of a right if that right cannot be realized except abroad. States do not normally have the power to ensure the realization of a right outside of their own jurisdiction. A policy to reject most requests of any category of persons to enter a country for purposes of family reunification, except under restrictive conditions or exceptional circumstances, violates the Convention."

74. Guy S. Goodwin-Gill, "Protecting the Human Rights of Refugee Children: Some Legal and Institutional Possibilities." in Children on the Move: How to Implement Their Right to Family Life, ed. Jaap Doek et al (The Hague: Kluwer Law International, 1996).

75. They are certainly treated as such by the UN Committee on the Rights of the Child, which has used peremptory language in this regard, recommending for example that Australia introduce legislation and policy reform "to guarantee that children of asylum seekers and refugees are reunified with their parents in a speedy manner." Concluding observations of the Committee on the Rights of the Child: 
Australia, UN doc. CRC/C/15/Add.79, para. 30 (10 Oct. 1997).

76. Summary Conclusions on Family Unity, UNHCR Global Consultations on International Protection Expert Roundtable (8-9 Nov. 2001) para. 1.

77. Executive Committee Conclusion No. 24 (XXXII) 1981, para.1: 'In application of the principle of family unity and for obvious humanitarian reasons, every effort should be made to ensure the reunification of separated refugee families.'

78. Human Rights Committee, 39 th $^{\text {th }}$ Session, 1990, General Comment 19 para. 5. Conclusions on Family Reunification, XIIIth Round Table on Current Problems in International Humanitarian Law (1988), International Institute of Humanitarian Law, para. 2.

79. The Refugees Act (130 of 1998), hereinafter the "Refugees Act."

80. According to the preamble, the Act is meant to give effect to the following international instruments to which South Africa has acceded: the Convention relating to the status of refugees (1951) ; The Protocol relating to the status of refugees (1967) ; The OAU Convention governing the specific aspects of the refugee problems in Africa(1969).

81. Art 7 'EXEMPTION FROM RECIPROCITY-Except where this convention contains more favourable provisions, a Contracting state shall accord to refugees the same treatment as is accorded to aliens generally'.

82. OAU Convention, Article II.

83. The 1951 Convention, Article 3 and the OAU Convention, Article IV.

84. Refugees Act Preamble-'WHEREAS the Republic of South Africa has acceded to the 1951 Convention Relating to Status of Refugees, the 1967 Protocol Relating to the Status of Refugees and the 1969 Organization of African Unity Convention Governing the Specific Aspects of Refugee Problems in Africa as well as other human rights instruments, and has in so doing, assumed certain obligations to receive and treat in its territory refugees in accordance with the standards and principles established in international law.'

85. Refugees Act, Section 6: Interpretation, application and administration of Act:

6. (1) This Act must be interpreted and applied with due regard to-

[...]

(d) The Universal Declaration of Human Rights (UN,1948);

(e) Any other relevant convention or international agreement to which the Republic is or becomes a party'.

86. Refugees Act, Section 3, Refugee status

Subject to Chapter 3, a person qualifies for refugee status for the purposes of this Act if that person-

(a) owing to a well-founded fear of being persecuted by reason of his or her race, tribe, religion, nationality, political opinion or membership of a particular social group, is outside the country of his or her nationality and is unable or unwilling to avail himself or herself of the protection of that country, or, not having a nationality and being outside the country of his or her former habitual residence is unable or, owing to such fear, unwilling to return to it; or

(b) owing to external aggression, occupation, foreign domination or events seriously disturbing or disrupting public order in either a part or the whole of his or her country of origin or nationality, is compelled to leave his or her place of habitual residence in order to seek refuge elsewhere; or

(c) is a dependant of a person contemplated in paragraph (a) or (b).

87. Refugees Act, Section 1 Definitions.

88. Edwards, Human Rights, 304.

89. Human Rights Committee, General Comment 28, Equality of rights between men and women (Article 3), U.N. Doc. CCPR/C/21/Rev.1/Add.10 (2000). See also Geraldine van Bueren, "The International Protection of Family Members' Rights as the 21st Century Approaches,"17(4) Human Rights Quarterly, 1995, 733-40.

90. International Committee of the Red Cross, Commentary on the Additional Protocols, Sandosz et al eds. (Geneva: Martinus Nijhoff, 1987) para. 2997.

91. UNHCR Executive Committee Conclusion, "Protection of the Refugee's Family," No. 88 (L) 1999 (b)(ii),

92. UNHCR, "Background Note: Family Reunification in the Context of Resettlement and Integration," Annual Tripartite Consultations on Resettlement (20-23 June 2001) para. 14.

93. Refugees Act, Section 27(b) states that a refugee is "enjoys full legal protection, which includes the rights set out in Chapter 2 of the Constitution ..."

94. South African Constitution (Act 108 of 1996).

95. Customary Marriages Act (120 of 1998).

96. Daniels v Campbell NO and others 2004 (5) SA 331 (CC).

97. Children-Section 28(1) Every child has the right-

(a) to a name and a nationality from birth;

(b) to family care or parental care, or to appropriate alternative care when removed from the family environment;

98. Dawood v Minister of Home Affairs 2000 (1) SA 997 (C).

99. Dawood v Minister of Home Affairs 2000, CCT35/99.

100. Johann de Waal and Iain Currie, The Bill of Rights Handbook; (Cape Town: Juta and Co., 2001) 372.

101.Dawood, at 1044C and Johnson $v$ The Minister of Home Affairs 1997 (2) SA 432 (C).

102. The government department responsible for the adjudication of refugees in South Africa

103. The author of this paper, as the current Director (since 2006) of the UCT Refugee Law Clinic, a legal aid clinic in Cape Town that provides assistance to refugees within the South African asylum process, has succeeded in making 
numerous such applications on behalf of refugee clients over the years.

104. Refugees Act Regulation 16(3).

105. The current manner in which the Department of Home Affairs haphazardly provides or denies refugee documentation to spouses and family members who join the main applicant at a later date is the subject of research being conducted by the author, which will also look to how refugee spouses are treated where they marry in terms of their customary law, either within or outside of South Africa's borders.

106. Refugees Act Regulation 16(1).

107 South Africa Immigration Act, No. 13 of 2002.

108. Jastram, Family Unity, 23.
109. Bosnia and Herzegovina Law on Immigration and Asylum, 23 February 1999, accessed on 15 August 2011 at http:// www.legislationline.org/documents/id/6284, Article 54.

110. The Political Refugees Act of Iraq, No. 51 (1971), Article 11.3.

Fatima Khan (BA, HDE, LLB, LLM) is the Director of the Refugee Rights Unit. She is an Attorney of the High Court of South African and lectures the Refugee Law Course to the final year LLB students as well as Refugee law and Human Rights course to students at a Masters level (LLM, MPhil) in the University of Cape Town's Faculty of Law. 
(C) Fatima Khan, 2011. This open-access work is licensed under a Creative Commons Attribution-NonCommercial 4.0 International License, which permits use, reproduction and distribution in any medium for non-commercial purposes, provided the original author(s) are credited and the original publication in Refuge: Canada's Journal on Refugees is cited. 